Olgu Sunumu

\title{
Anterior İmplant Destekli Sabit Protezlerde Yumuşak Doku Konturunun Oluşturulması: 4 Vaka Sunumu
}

\author{
Obtaining Soft Tissue Contour for Anterior Implant \\ Supported Fixed Prosthesis: A Report of 4 Cases
}

Ceyda Başak İnal ${ }^{1}$ (D), Öykü Karaoğlu ${ }^{2}$ (D) Merve Bankoğlu Güngör ${ }^{3}$ (D), Seçil Karakoca Nemli ${ }^{4}$

\section{ÖZET}

Eksik dişlerin yerine konmasında implantlar sıklıkla tercih edilmektedir. Dental implantlardaki gelişmeler sayesinde osseoentegrasyon süreleri kısalmış ve implantların geçici protezler ile immediat yüklenmesi gündeme gelmiştir. Bu sayede özellikle anterior bölgedeki implant destekli restorasyonlarda hem hastanın estetik beklentileri kısa sürede karşılanmakta hem de implant çevresindeki yumuşak doku konturu doğal dişin çıkış profiline benzer olarak şekillendirilebilmektedir. İmplantların immediat yüklenemediği durumlarda ise geleneksel iyileşmeyi takiben hazırlanan geçici restorasyonlar yardımıyla yumuşak doku şekillendirilebilmektedir. Bu vaka sunumunda anterior bölgede implant tedavisini takiben immediat yüklenen geçici protezlerin ve geleneksel iyileşme süreci sonunda hazırlanan sabit geçici protezlerin yapım aşamaları anlatılmaktadır. Bu aşamada hastalar geçici protezlerini estetik olarak kabul edilebilir bulmuştur. Yumuşak doku konturu oluşturulduktan sonra da daimi protezleri yapılmıştır. Takip sürecinde implant çevresi sert ve yumuşak dokularda herhangi bir komplikasyona rastlanmamış ve hastaların protezlerine ilişkin estetik ve fonksiyonel olarak memnuniyetleri gözlemlenmiştir.

Anahtar Kelimeler: Acil dental implant yerleştirme; Diş implantı; Geçici diş restorasyonu

\begin{abstract}
Dental implants are frequently preferred to replace missing teeth. Osseointegration period of the implants has been shortened due to the improvements in dental implants. Immediate restoration of the dental implants, especially in the anterior region, fulfill patients' esthetic expectations and also generate natural soft tissue emerging profile. In cases which immediate loading of implants is not possible, soft tissue contouring can be performed by using the temporary crowns after the traditional healing period. In this case report, immediate temporary crown fabrication procedures following the implant placement and temporary crown fabrication procedures after the traditional healing period in the anterior region were described. Patients were satisfied with esthetic appearance of temporary restorations at this stage. The permanent prostheses were delivered after the soft tissue contour was obtained. In the follow-up process, there was no periimplant tissue complication, and the patients were satisfied with the esthetical and functional results of the prostheses.
\end{abstract}

Keywords: Immediate dental implant loading; Dental implants; Temporary dental restoration

Makale gönderiliş tarihi: 07.07.2021 ; Yayına kabul tarihi: 24.10.2021

Illetişim: Dr. Ceyda Başak İnal

Gazi Üniversitesi Diş Hekimliği Fakültesi, Protetik Diş Tedavisi Ana Bilim Dalı Bişkek Cd. (8.Cd.) 1.Sk. No:4 06490 Emek-ANKARA

E-posta: ceydabasak.inal@gazi.edu.tr

1 Dt., Gazi Üniversitesi Diş Hekimliği Fakültesi, Protetik Diş Tedavisi Ana Bilim Dalı, Ankara, Türkiye.

2 Dt., Gazi Üniversitesi Diş Hekimliği Fakültesi, Protetik Diş Tedavisi Ana Bilim Dalı, Ankara, Türkiye.

${ }^{3}$ Doç. Dr., Gazi Üniversitesi Diş Hekimliği Fakültesi, Protetik Diş Tedavisi Ana Bilim Dalı, Ankara, Türkiye.

${ }^{4}$ Prof. Dr., Gazi Üniversitesi Diş Hekimliği Fakültesi, Protetik Diş Tedavisi Ana Bilim Dalı, Ankara, Türkiye.

Bu olgu sunumunda anlatılan vakalardan ikisi Gazi Üniversitesi Diş Hekimliği Fakültesi 1. Genç Akademisyenler Kongresinde poster bildiri olarak sunulmuştur (20-21 Şubat 2020, Ankara, Türkiye). 


\section{GíRiş}

Günümüzde diş eksikliklerinin tedavisinde implantlar sıklıkla kullanılmaktadır. Özellikle tek diş eksikliklerinin restorasyonu için uzun süreli başarı ve sağ kalıma sahip olan dental implantlar dişsiz boşluğa komşu destek dişlerin korunduğu koruyucu bir tedavi seçeneğidir. ${ }^{1}$ Dental implantların tasarımlarında ve yüzey özelliklerindeki gelişmelerle birlikte osseoentegrasyon süresinin kısalması, özellikle ön bölgede diş eksikliği olan hastaların protetik tedavi sürecini kısaltmaktadır.2

Ön bölge tek diş eksikliklerinin implant destekli kronlar ile tedavisinde yumuşak dokuların doğal konturunun sağlanabilmesi zorlayıcı bir süreç gerektirebilmektedir. Çünkü diş çekimlerini takiben çekim soketini çevreleyen krestal kemikte meydana gelen rezorbsiyon sonucu interdental papil kaybı ve destek dokularda hacim kaybı görülür. Ayrıca dişsiz boşluğa yerleştirilen implantın boyut ve şekil olarak doğal diş kökünden farklı olması, implant tarafından desteklenen kronun hastanın doğal diş ve dişeti formundan farklılık göstermesine yol açar. İmplant destekli restorasyonun estetik görünümünü olumsuz etkileyerek genel tedavi başarısını sınırlayan bu durumun engellenmesi için günümüzde farklı yaklaşımlar uygulanabilmektedir. Bu yaklaşımlar arasında; diş çekimi yapıldığı seansta immediat implant yerleştirilerek immediat geçici restorasyonun yapımı, iyileşmiş çekim bölgesine yerleştirilen implant üzerine immediat geçici restorasyonun yapımı ve geleneksel osseoentegrasyon sürecini tamamlamış implantın üzerine ikinci aşama cerrahiyi takiben geçici restorasyon yapımı yer almaktadır. Her üç durumda da geçici restorasyonlar ile implant çevresi yumuşak dokuda doğal dişeti konturu oluşturulabilmektedir. Genel sistemik ve lokal dental durumu açısından dikkatli bir değerlendirme sonucu uygun vaka seçimi ile bu yaklaşımlardan uygun olanı seçilerek estetik ve fonksiyonel olarak başarılı, uzun dönem stabil implant destekli anterior restorasyonlar ortaya koyulabilir. ${ }^{3,4}$

Diş çekimi yapıldığı seans çekim soketine immediat implant yerleştirilerek geçici restorasyonun yerleştirilmesi hem çekim bölgesinde sert ve yumuşak dokuları koruyarak rezorbsiyonun azaltılmasını sağlayan hem de hastanın dişsizlik dönemini ortadan kaldırarak psikolojik avantajlar sağlayan bir tedavi yaklaşımıdır. ${ }^{1,3}$ Ancak bu tedavinin uzun dönem başarısında hasta seçimi önem taşımaktadır. İmmediat implant yerleştirilmesi için çekim bölgesinde enfeksiyon bulgusu olmaması, soket duvarlarının primer stabilitey sağlayacak yükseklikte olması, bukkal kemiğin en az $1 \mathrm{~mm}$ kalınlıkta olması ve bölgedeki yumuşak dokunun kalın biyotipe sahip olması gerekmektedir. ${ }^{5}$ İmplant yerleştirilmesini takip eden 1 hafta içinde protetik restorasyonun hazırlanması olarak tanımlanan implantların immediat yüklenmesi için gerekli olan yüksek primer stabilite sağlanmalı, hastanın iyi bir ağız hijyeni olmalı ve sigara kullanmamalı, parafonksiyonel alışkanlığı olmamalı, sentrik ve eksentrik oklüzyonda temassızlık sağlanmalıdır. ${ }^{6,7}$ İmmediat yüklemenin ikinci cerrahi işlemi gerektirmemesi ve hastaların estetik görünümlerinin daha hızlı restore edilebilmesi gibi avantajları bulunmaktadır. ${ }^{6}$

Anterior bölgede geleneksel osseoentegrasyon sürecini takiben implant destekli restorasyon yapımında geçici restorasyonlar yardımıyla yumuşak dokuIarın şekillendirilmesi estetik başarı için gerekli hale gelmiştir. İkinci aşama cerrahi esnasında hazırlanarak yerleştirilen geçici restorasyon belirli sürelerde modifiye edilerek yumuşak dokular şekillendirilmektedir. Osseoentegrasyon süresine ilave olarak ortalama 8 haftalık bir yumuşak doku şekillendirmesi ve artan seans sayısı bu işlemin dezavantajları olarak görülse de doğal çıkış profili sayesinde estetik olarak mükemmel implant destekli restorasyonlar ancak bu şekilde elde edilebilmektedir. ${ }^{8}$

$\mathrm{Bu}$ vaka sunumunun amacı estetik olarak önemli olan anterior bölgede implant destekli kron protezleri uygulanan 4 hastada farklı implant yerleştirme ve farklı yükleme zamanları ile yumuşak doku şekillendirilmesinin anlatılmasıdır.

\section{VAKA SUNUMU}

Bu vaka sunumunda implant destekli restorasyonlarının yapımı amacıyla Gazi Üniversitesi Diş Hekimliği Fakültesi, Protetik Diş Tedavisi Anabilim Dalı'na başvuran 4 hastanın tedavi aşamaları anlatılmaktadır.

\section{Vaka 1: Üst santral dişin (21) geçici kron ile immediat yüklenmesi}

Üst sol santral kesici diş eksikliği olan hastada dişsiz boşluğa implant yerleştirildi. Aynı seansta standart geçici dayanak (Temporary snap abutment, Nobel 

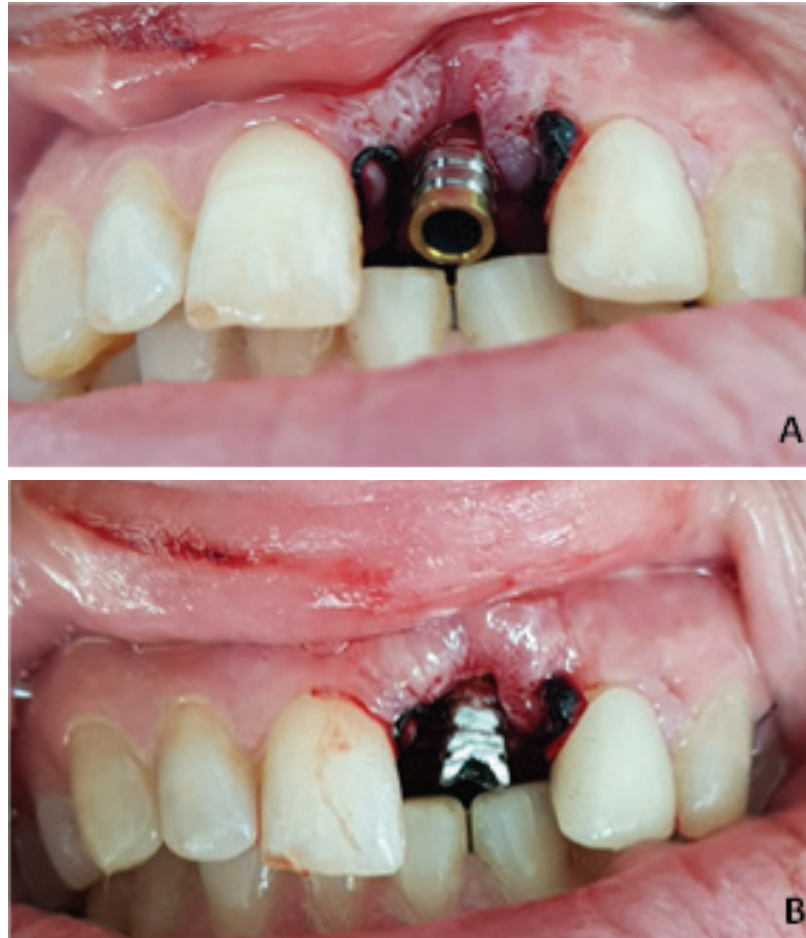

Resim 1. Geçici dayanağın görünümü $A)$ Geçici dayanak şekillendirilmeden önce B) Geçici dayanak şekillendirildikten sonra

Biocare, Göteborg, İsveç) hasta ağzında kontrol edildi, ağız dışında oklüzyon ile uyumlu olacak şekilde aşındırıldı ve tekrar implant üzerine yerleştirildi (Resim 1). Hastaya daha önce hazırlanmış olan şeffaf akrilik plak kullanılarak, geçici dayanak üzerinde santral diş formunda akışkan kompozit (i-flow, i-dental, Siauliai, Litvanya) ile kron şekillendirildi (Resim 2). Polimerizasyon tamamlandıktan sonra kron ile dayanak birlikte çıkarılarak eksik alanlara akışkan kompozit ilavesi yapıldı (Resim 3).

Kronun servikal bölgesi aşındırıcı frez yardımıyla şekillendirildi. Vida yuvası hazırlayıcı frez (Apical drill; Nobel Biocare, Göteborg, İsveç) ile vida deliği açıldı (Resim 4). Hazırlanan kronun polisaj lastiği ile mekanik polisajı yapıldı. Yerleştirilen kronun artikülasyon kağıdı ile oklüzal temas noktaları tespit edildi. Aynı zamanda alt çenenin lateral ve protruziv hareketlerinde karşıt dişlerle temasların elimine edilmesi amacıyla aşındırmalar yapıldı (Resim 5). Kron, tüm uyumlamaları tamamlandıktan sonra implant üzerine vidalandı. Vida deliği teflon bant ve kompozit rezin (Charisma; Heraeus Kulzer, Hanau, Hessen, Almanya) ile kapatılarak tekrar oklüzal uyumlamalar yapıldı. İmplant yerleşimi ve geçici kronun takılmasından 1 hafta sonra süturlar alınarak kontrol edildi.
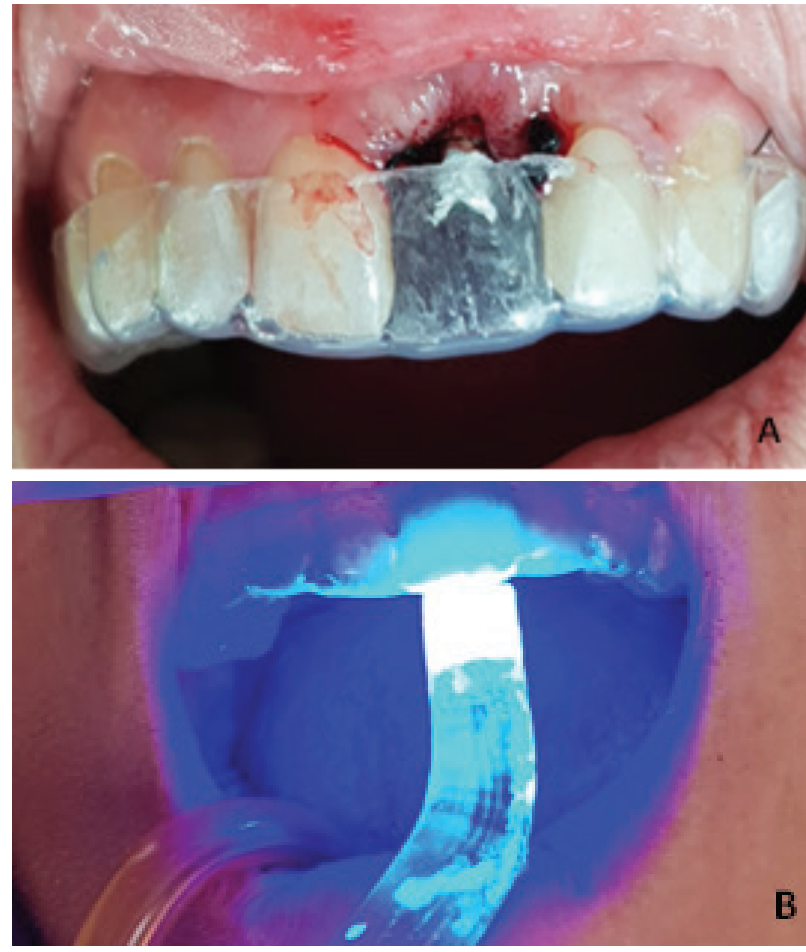

Resim 2. Geçici kronun hazırlanması A) şeffaf plağın yerleştirilmesi B) Akışkan kompozit ile kron formunun oluşturulması

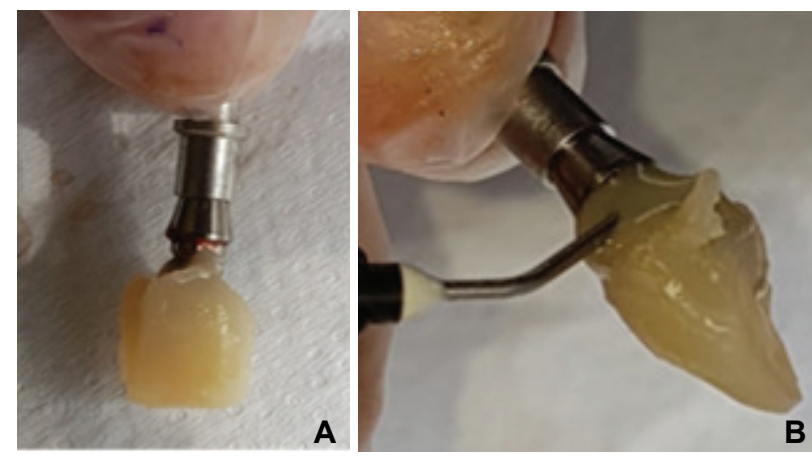

Resim 3. Geçici kronun tamamlanması A) Geçici kronun ağızdan çıkarıldıktan sonraki ilk hali B) Eksik bölgelere akışkan kompozit ilavesinin yapılması

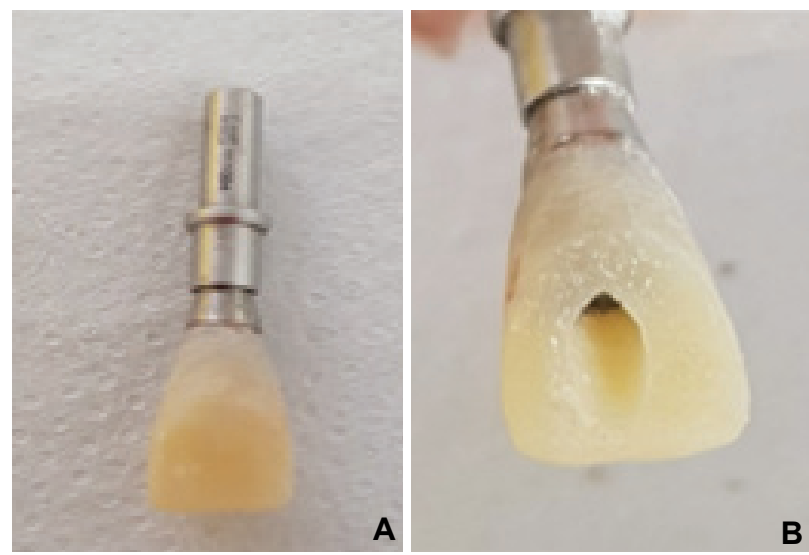

Resim 4. A) Kronun servikal bölgesinin şekillendirilmiş hali B) Vida deliğinin açılması 

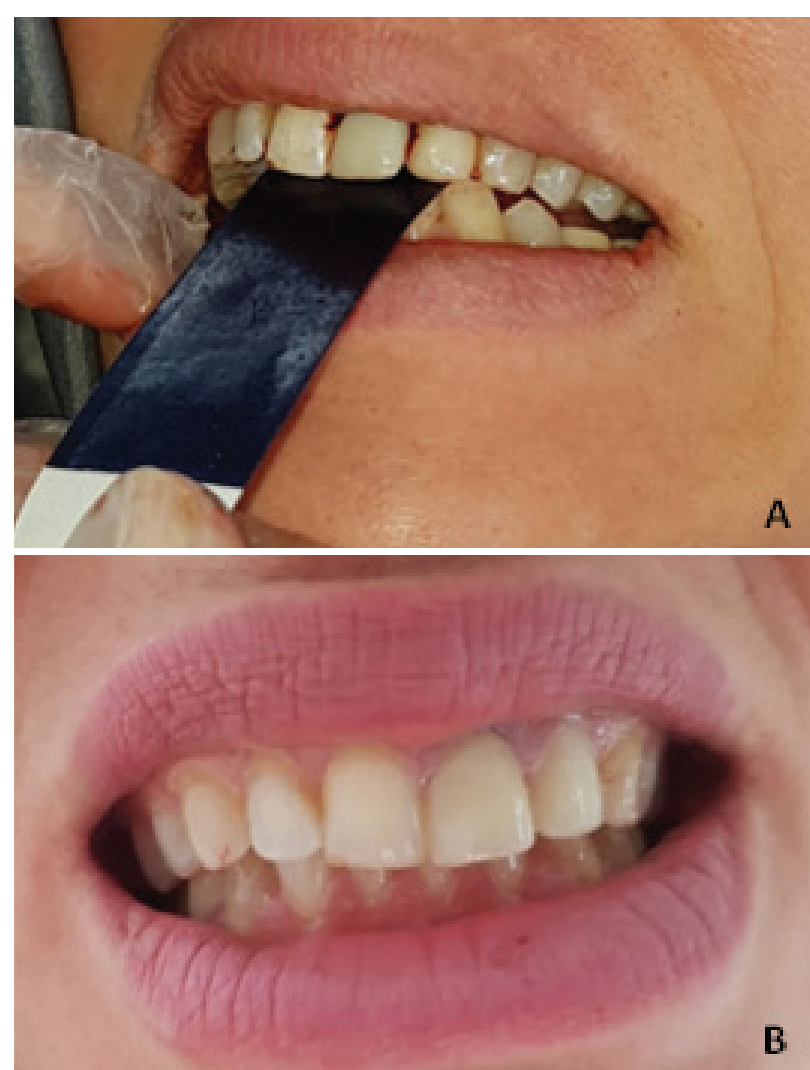

Resim 5. A) Oklüzal ve protruziv temasların kontrolü B) 3 ay sonraki ağız içi görünüm
Üç aylık iyileşme süresi sonunda geçici restorasyonun periyodik olarak modifiye edilmesi ile implant çevresi yumuşak dokuların şekillendirilmesine başlandı. Her 2 haftada bir yapılan kontrol seanslarında geçici krona gerekli ilave ve aşındırmalar yapılarak yumuşak doku şekillendirildi. Toplam 10 haftalık yumuşak doku şekillendirmesi ile istenen doku konturu elde edildikten sonra daimi restorasyon yapımına geçildi.

Daimi protez için ölçü almadan önce, hastanın geçici protezine göre hazırlanan yumuşak doku konturunun kopyalanması amacıyla geçici kron ve dayanak bütünü analog ile birleştirilerek silikon ölçü materyaline (Optosil; Heraeus Kulzer, Hanau, Hessen, Almanya) servikal 1/3'lük kısmı içinde kalacak şekilde gömüldü. Silikon sertleştikten sonra çıkarılarak, implant analoğu üzerine ölçü postu vidalandı ve silikon kalıp içine tekrar yerleştirildi. Bu kalıpta geçici kron formundan kalan boşluğa patern rezin (Pattern Resin LS; GC America, Alsip, IL, ABD) yerleştirilerek polimerizasyonu tamamlandı (Resim 6). Gingival bölgede geçici kronun şeklini alan ölçü postu hasta ağzına yerleştirilip daimi ölçüler kapalı kaşık yönte-

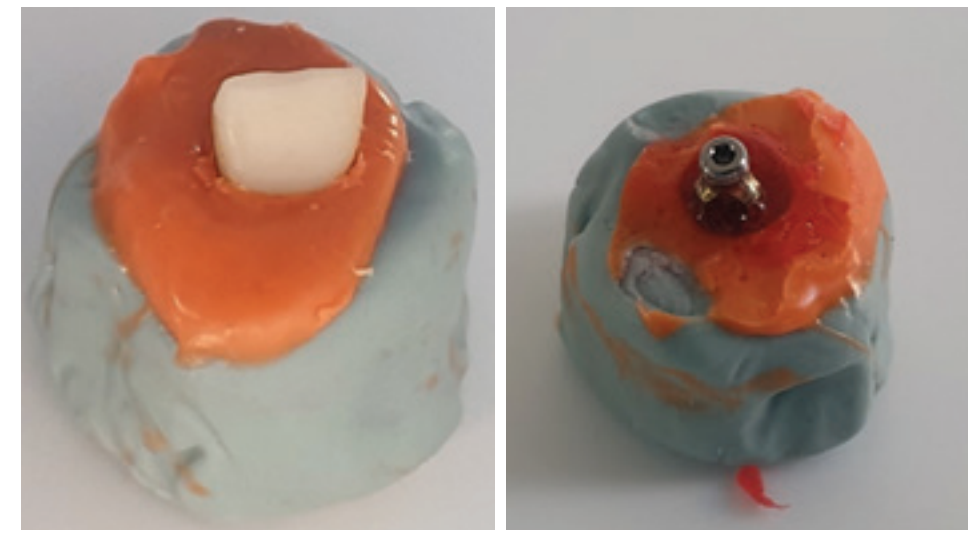

Resim 6. Geçici kronun çıkış profilinin kopyalanması

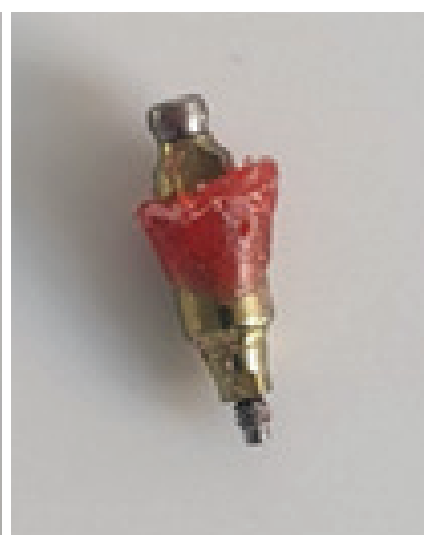

mi kullanılarak polivinil siloksan ölçü maddesi (Elite HD+, Zhermack SpA, Rovigo, İtalya) ile alındı ve çaIışma modeli elde edildi. Model üzerinde, implant ile birleşimi titanyumdan oluşan zirkonya hibrit dayanak üretildi.

Hibrit dayanak ağız içinde kontrol edildikten sonra zirkonya destekli kronun alt yapı ve dentin provaları yapıldı. Sentrik oklüzyondaki prematür temaslar, la- teral ve protrusiv hareketlerdeki çatışmalar giderildi. Hibrit dayanak hasta ağzına yerleştirildikten sonra dayanak vidası tork kontrol cihazı ile $15 \mathrm{Ncm}$ tork ile sıkıştırıldı ve vida deliği kompozit rezin ile kapatıldı. Zirkonya destekli seramik kronun glaze işlemi tamamlandıktan sonra rezin siman (Totalcem, Itena, Paris, Fransa) ile simante edildi (Resim 7). Hastanın 6 ay sonra ve 3 yıl sonra kontrol periapikal radyografları alındı (Resim 8). 


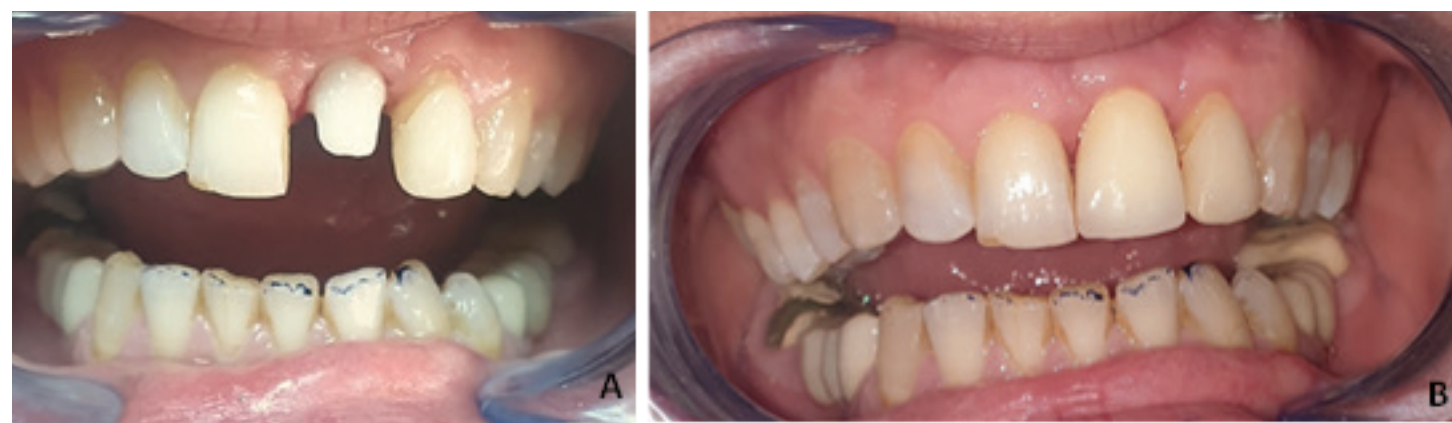

Resim 7. A) Hibrit dayanağın hasta ağzında kontrol edilmesi B) Seramik kronun simante edilmesi

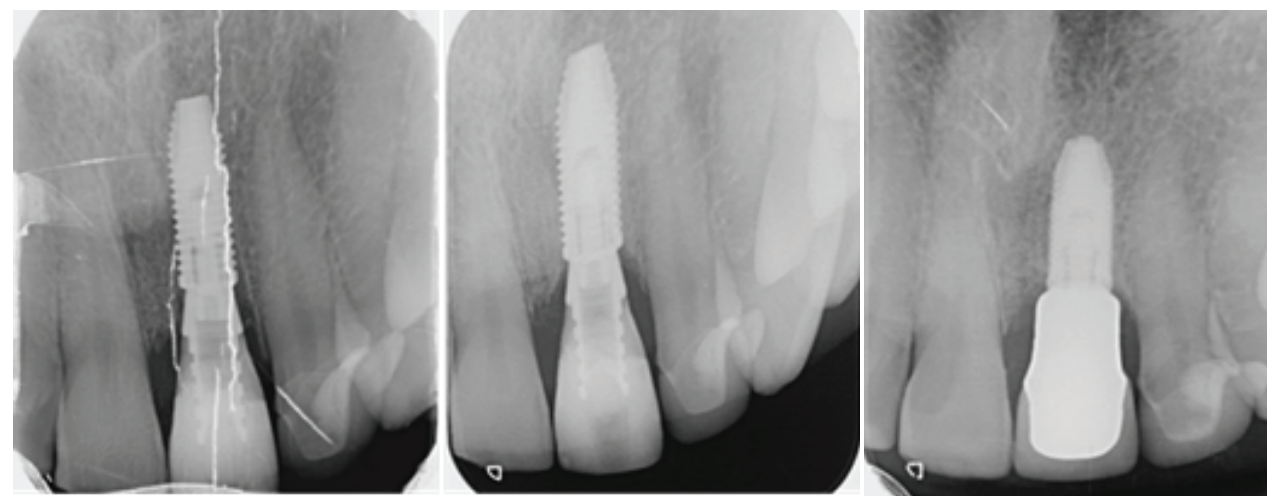

Resim 8. Hastanın geçici protezden hemen sonra, 6 ay sonra ve 3 yıl sonra alınan radyografları

\section{Vaka 2: Alt kanin (33) dişin geçici kron ile immediat yüklenmesi ve yumuşak doku konturunun oluşturulması}

Endodontik tedavili alt sol kanin dişin kökü içine alan kırığı sebebiyle çekimine karar verildi. Diş çekiminin yapıldığı seansta hastaya implant yerleştirildi ve geçici restorasyon yapıldı. İmplant yerleştirildikten sonra, geçici PEEK (polietereterketon) (Geçici abutment, MegaGen, Gyeongsang, Güney Kore) dayanak üzerine uygulanarak yükseklik ve genişlik olarak kron boyutuna göre ayarlandı (Resim 9).
Geçici dayanağa yumuşak doku konturunu sağlayacak ve komşu dişlerle temasta olacak şekilde yapılan ilaveler ile kanin diş formu elde edildi. Ağız içine yerleştirilerek kronun formu kontrol edildi. Lingualde olacak şekilde vida deliği açık bırakıldı. Kron vidalandıktan sonra teflon bant ve kompozit rezin ile vida deliği kapatılarak oklüzyon kontrol edildi (Resim 10). Geçici restorasyonun takip ve modifikasyonu ile yumuşak doku şekillendirilmesi ve daimi restorasyon hazırlanması Vaka 1'de anlatılan şekilde yapıldı.
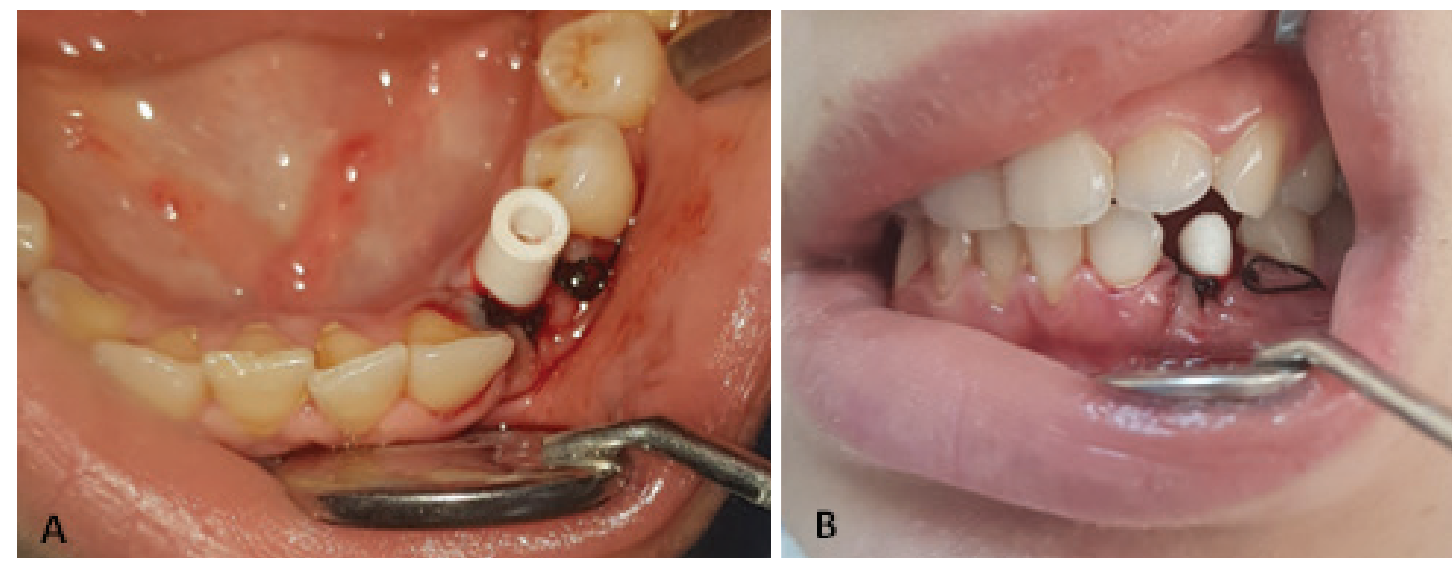

Resim 9. Geçici dayanağın yerleştirilmesi A) Standart dayanağın ilk görünümü B) Preparasyondan sonraki görünümü 


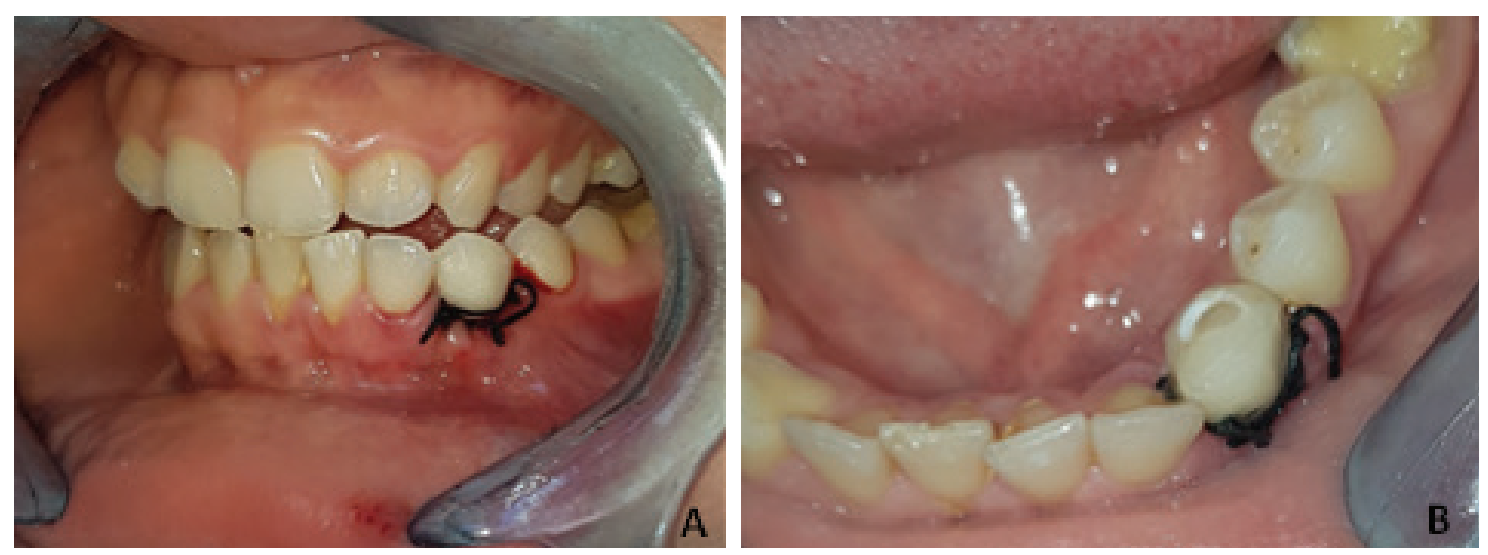

Resim 10. Geçici kronun yerleştirilmesi $A$ ) Bukkalden görünümü B) Lingualdeki vida deliğinin görünümü

\section{Vaka 3: Üst santral (21) diş eksikliğinde yumuşak doku konturunun oluşturulması ve implant destekli sabit restorasyonu}

Üst sol santral diş eksikliği olan hasta, implant yerleştirilmesinden 3 ay sonra kliniğimize başvurdu. Hastadan alınan ölçüler ile öncelikle yumuşak doku konturu oluşturmak amacıyla geçici kron hazırlandı. Dişeti seviyesinin komşu dişin zenith noktası ile aynı seviyede olması amacıyla gingivektomi yapıldı (Resim 11).
Geçici kron 3 hafta sonra kontrol edildi. İstenen yumuşak doku konturunun sağlanması ile daimi protezin yapımına başlandı. Geçici kronun çıkış profili silikon ölçü maddesi yardımıyla kopyalandı ve ölçü postuna aktarıldı. Polivinil siloksan ölçü maddesi ile alınan ölçülerden elde edilen alçı modeller üzerinde uygun hazır dayanak seçildi. Hazırlanan zirkonya altyapı dayanak formunda prepare edildi ve vida deliği açıldı. Daha sonra zirkonya altyapı ve dayanak birbirine rezin siman ile yapıştıııldı. Altyapı-dayanak bileşkesi üzerine hazırlanan cam seramik kron rezin siman ile simante edilerek restorasyon tamamlandı (Resim 12).

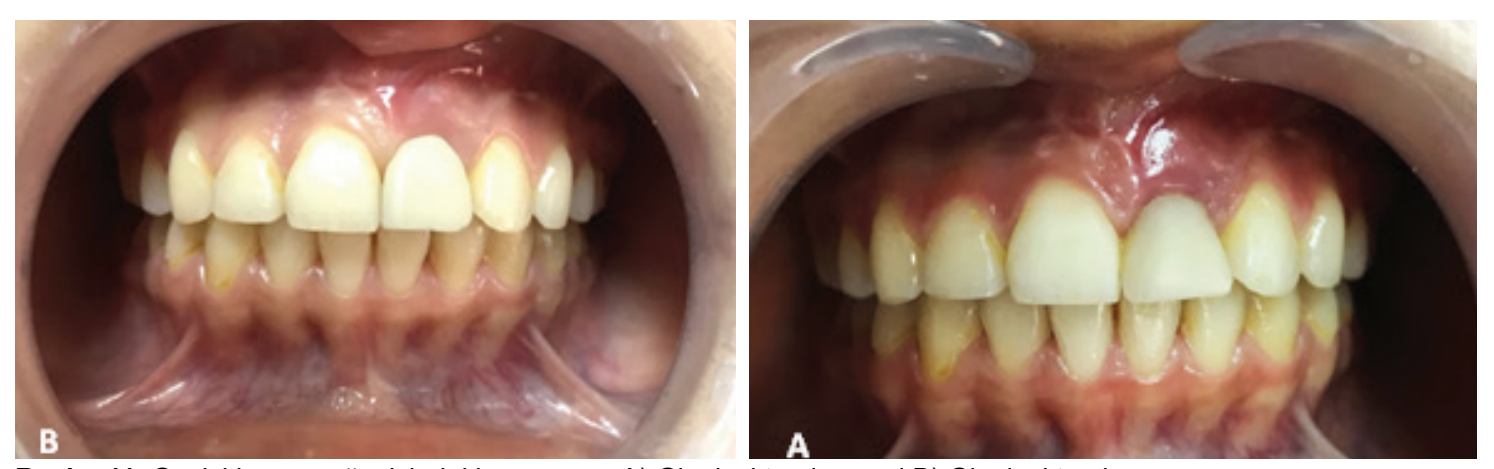

Resim 11. Geçici kronun ağız içindeki görünümü A) Gingivektomi öncesi B) Gingivektomi sonrası
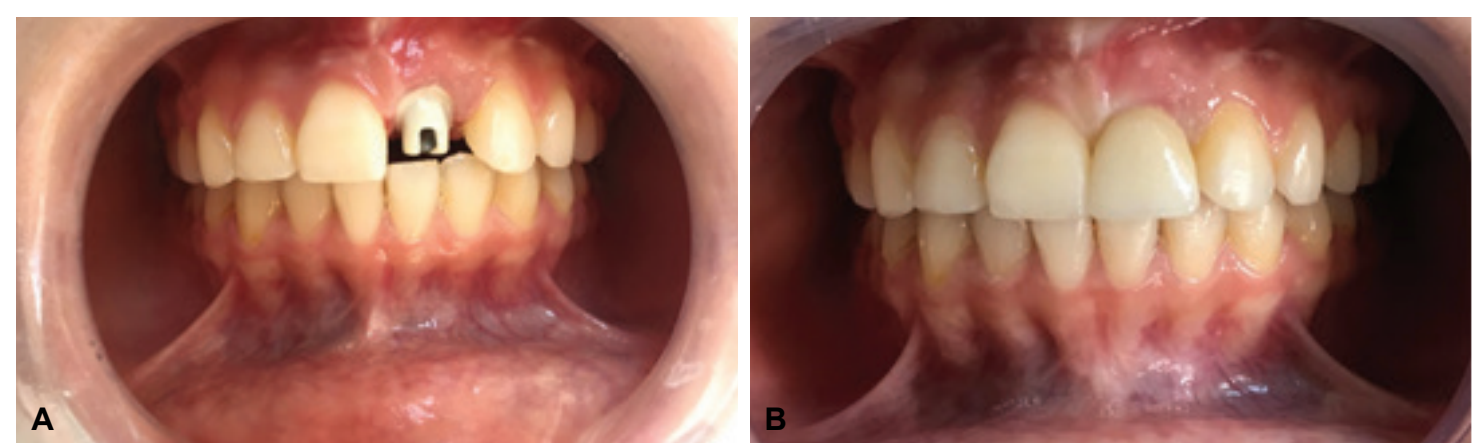

Resim 12. Daimi protezin aşamaları A) Zirkonya altyapı ile birleştirilen dayanağın ağız içindeki görünümü B) Daimi kronun simantasyonu 


\section{Vaka 4: Osseoentegrasyonu tamamlanan hastada implant destekli restorasyonun değişimi öncesinde yumuşak doku konturunun oluşturulması}

40 yaşında kadın hastanın, maksiller sağ santral diş bölgesine daha önceden yerleştirilmiş olan implantın (Straumann, Basel, İsviçre) etrafında meydana gelen kemik kaybı nedeniyle ilgili bölgedeki peri-implant dokusunda düzenlemeler yapıldı. İlave cerrahi işlemler sırasında hastanın mevcut restorasyonu çıkarıldı. Peri-implant dokusunda uygun bir çıkış profili sağlayabilmek için mevcut zirkonya dayanak üzerine kompozit rezin tabakalar halinde uygulanarak polimerize edildi ve vida tutuculu geçici kron yapıldı. Hasta belirli aralıklarla kontrole çağrılarak, implant çevresindeki yumuşak doku kontrol edildi ve gerekli görüldüğünde kompozit geçici krona ilaveler yapıldı (Resim 13). Uygun bir diş eti çıkış profili sağlandığında, daimi restorasyonun yapımına geçildi. Şekillendirilmiş implant çevresi yumuşak dokunun ölçüye aktarılması Vaka 1'de anlatıldığı şekilde yapıldı.

Hibrit dayanağın hasta ağzında kontrol edilmesinin ardından (Resim 14) zirkonya destekli kron üretildi (Resim 15).
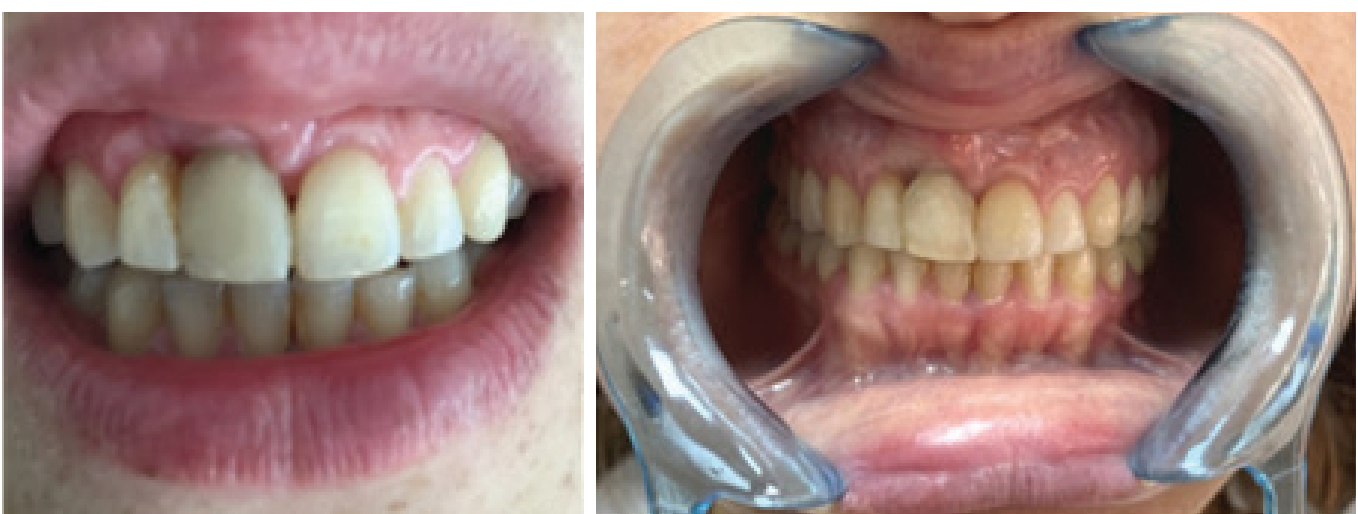

Resim 13. Prefabrike zirkonya dayanak üzerine uygulanan vida tutuculu kompozit rezin geçici kron
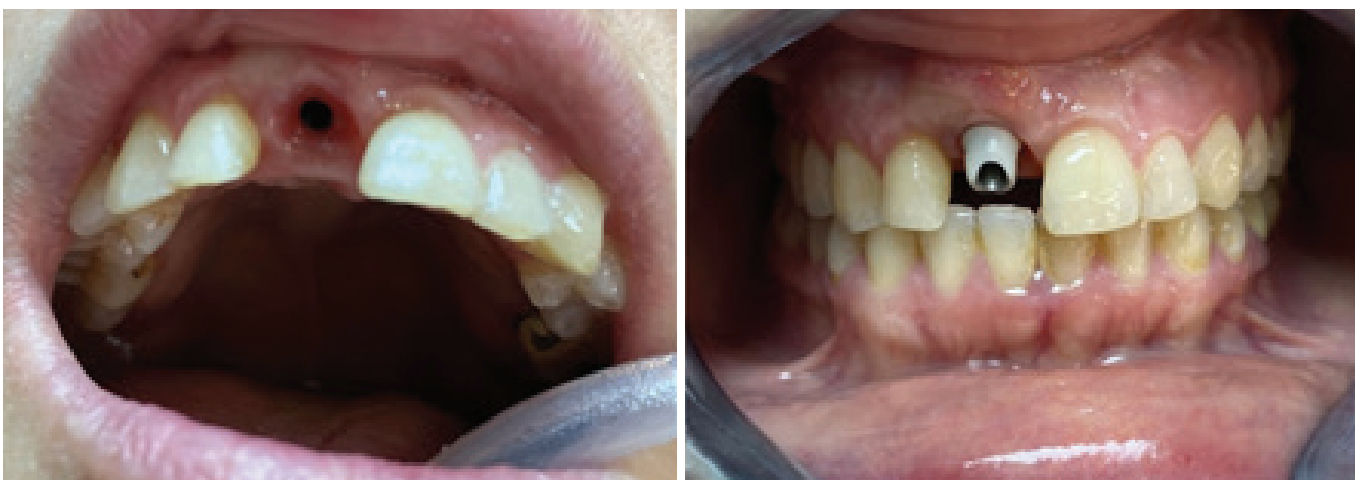

Resim 14. Hibrit dayanağın hasta ağzında kontrol edilmesi

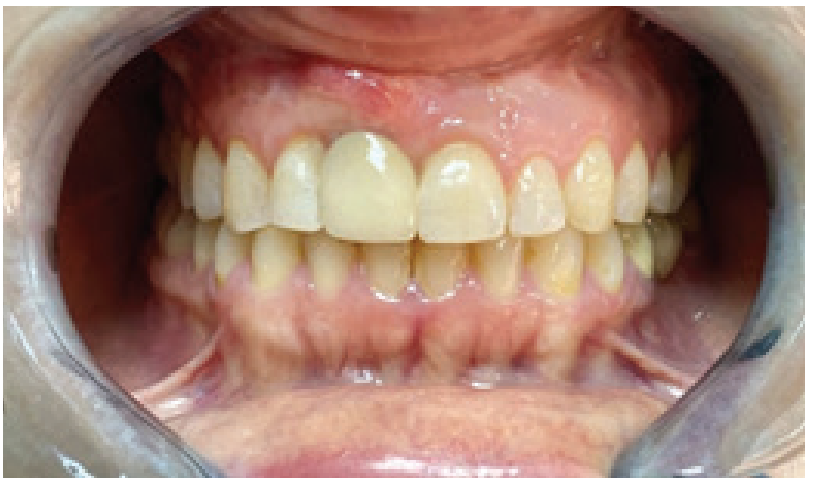

Resim 15. Simante edilen restorasyonun ağız içi görünümü 


\section{TARTIŞMA}

Günümüzde implant başarısı osseoentegrasyonun yanı sıra hastaya estetik ve fonksiyonu en kısa sürede iade eden doğal görünümlü ve uzun dönem sağlıklı restorasyonların yapımından geçmektedir. İmplantların eksik dişlerin tedavisinde kullanılması zamanla geleneksel diş destekli sabit bölümlü protezlere göre daha sık tercih edilen ve kabul gören bir tedavi seçeneği haline gelmiştir. ${ }^{9}$ Ancak diş destekli sabit protezlere göre implant destekli protezlerin geleneksel tedavi süreci daha uzun sürmektedir. Diş çekimini takiben soketin tekrar kemikle dolması ortalama 3-4 ay sürerken, implant yerleştirilmesi sonrasında yumuşak dokunun tamamen iyileşmesi ve implant etrafında kemik oluşumu için ilave yaklaşık 3 ay daha beklemek gerekebilmektedir. Özellikle estetik bölgede bu süreci kısaltmak için implant yerleşimini takiben immediat geçici restorasyonlar hazırlanabilmektedir. ${ }^{3}$ Bu vaka sunumunda, Vaka 1 ve Vaka 2'de implant yerleşimini takiben immediat geçici protezlerin hazırlanma aşamaları Vaka 3 ve Vaka 4 'te ise geleneksel iyileşme sürecini takiben geçici restorasyonlar kullanılarak implant çevresinde yumuşak doku konturunun oluşturulması anlatılmıştır.

İmplant gövdelerinin primer stabiliteyi arttıran yiv tasarımları ve yüzeylerinin osseoentegrasyonu hızlandıran modifikasyonları immediat ve erken yükleme protokollerinin uygulanmasına olanak sağlamaktadır. Bu sayede iyileşme süresinin azalmasıyla implant tedavisinin tercih edilme sıklığı artmaktadır. ${ }^{10}$ İmmediat yükleme ile protetik tedavinin yapılabilmesi için implantın primer stabilitesinin yeterli olması gerekmektedir. Primer stabilite anterior bölgede posterior bölgeye göre daha kolay sağlanabilmekte ve posterior bölgedeki restorasyonların yüksek çiğneme kuvvetleri altında olması nedeniyle immediat yüklemede başarısızlık posterior bölgede daha sık görülebilmektedir. ${ }^{11}$ Ayrıca immediat yükleme, anterior bölgede estetik gereksinimin yüksek olması sebebiyle önem kazanmaktadır.

İmmediat yükleme, implant yerleştirilmesinin hemen sonrasında veya takip eden 1 hafta içinde fonksiyonda olan ya da olmayan bir protezin uygulanması olarak tanımlanmaktadır. ${ }^{4}$ Ancak immediat yükleme her vaka için kullanılmaya uygun değildir. İmmediat yükleme yapılıp yapılamayacağı öncelikle implantın primer stabilitesine göre değerlendirilmektedir. ${ }^{3}$
$35 \mathrm{~N}$ ve üzerindeki tork değerleriyle yerleştirilen ve 70 ve üzeri ISQ (implant stabilite birimi) değerlerine sahip implantların primer stabilitesi başarılı bulunmaktadır. ${ }^{6,12}$ Yerleştirilen geçici protezin sadece statik pozisyonda oklüzal temasının olması, latera ve protruziv hareketlerde temasının engellenmes gerekmektedir. ${ }^{1}$ Ayrıca hastanın genel sağlığının ve oral hijyeninin iyi olması gerekirken bruksizm gibi parafonksiyonel bir alışkanlığı olmamalıdır. ${ }^{6}$ Bu vaka sunumunda anlatılan Vaka 1 ve Vaka 2, yapılan klinik ve radyolojik muayene sonucunda immediat restorasyon için uygun bulunmuş ve implant cerrahisi esnasında primer stabilitenin de yeterli olduğu gözlemlenmiştir.

İmmediat ve geç yükleme prosedürlerinin karşılaştırıldığı 5 yıllık takipli bir çalışmada ${ }^{13}$, komplikasyon, implant sağ kalımı, estetik ve hasta beklentileri açısından anlamlı farka rastlanmamıştır. Tek kronlar üzerinde yapılan iki yıllık prospektif çalışmaya ${ }^{11}$ göre immediat yükleme implantın sağ kalımı üzerinde olumsuz etkiye neden olmamıştır. Yapılan bir meta-analiz çalışmasında ${ }^{14}$ ise, immediat yükleme geç yüklemeye göre daha yüksek implant başarısızıı̆ı gösterse de marjinal kemik seviyesi ve sondlama derinliğinde belirgin fark gözlenmemiştir. Ayrıca immediat yükleme ve erken yükleme karşılaştırıldığında benzer implant sağ kalımı ve marjinal kemik seviyeleri gözlemlenmiştir. ${ }^{14}$ Estetik bölgede tek diş implant restorasyonunda immediat geçici uygulanan ve uygulanmayan hastaların karşılaştırıldığı 5 yıllık takipli çalışmada, tüm grupların \%100 sağ kalım oranına sahip olduğunu ve immediat geçici uygulanan grubun elde edilen yumuşak doku nedeniyle daha estetik sonuçlar verdiğini bildirmiştir. ${ }^{15}$ Estetik bölgede dar çaplı implant tedavisini takiben geçici restorasyonların uygulandığı hastaların 1 yıllık takibi sonucu çevre sert ve yumuşak doku cevabı başarıl bulunmuş, sondlamada kanama ve plak birikimi belirgin olarak değişmemiştir. ${ }^{7}$

Bu vaka sunumunda, Vaka 1'in 3 yıllık takibi sonucu implant çevresi kemik kaybı gözlenmezken yumuşak dokuda bir miktar çekilme gözlemlenmiştir. Vaka 2'nin 2 yıllık takibi sonucu sert ve yumuşak dokuda belirgin değişime rastlanmamış ve hastanın tedaviden memnuniyeti gözlemlenmiştir. Vaka 4'te 1 yıllık takip sonucunda yumuşak doku konturunun devamIılık gösterdiği belirlenmiştir. Ayrıca takip süresince mekanik veya biyolojik komplikasyona rastlanma- 
mıştır. Ancak kanıta dayalı klinik sonuçlar ortaya koyabilmek için iyi tasarlanmış prospektif çalışmalara gereksinim duyulmaktadır. Yeterli bilimsel kanıt oluşturacak sayıda hasta üzerinde, standardize edilmiş kemik seviyesi ölçümü ve periodontal indeksler gibi objektif değerlendirmelerin yapıldığı ve en az 5 yılı kapsayan uzun takip sürelerinde gerçekleştirilen klinik çalışmalar ile anterior tek diş eksikliklerinde uygulanan implant tedavileri ve farklı klinik protokollerin sonuçları ortaya koyulmalıdır.

Üst çeneye uygulanan tek immediat implantlar ve immediat geçici restorasyonların değerlendirildiği sistematik derlemede, 1 yılın sonunda ortalama kemik kaybı 0.2-0.5 mm arasında bulunmuş (kabul edilebilir değer <1-1.5 mm), dişeti seviyelerinin korunduğu bildirilmiştir. Ancak interdental papilleri korumak için implant ve protez zamanlamasından çok diş çekimi ve implantın yerleştirilmesi sırasında bölgedeki kemik miktarının korunması önem taşımaktadır. ${ }^{16}$ Bukkal mukoza seviyesinin değerlendirildiği bir çalışmada, immediat yüklenen implantların bukkal mukozasındaki çekilme miktarı, geleneksel (geç yükleme) prosedürün uygulandığı implantlardaki çekilme miktarının neredeyse üç katı olduğu kaydedilmiştir. ${ }^{17}$ Ancak immediat ve geç yükleme arasında dişeti seviyeleri bakımından anlamlı fark olmadığını gösteren çalışmalar da mevcuttur. ${ }^{18,19}$

İmplant firmaları geçici protezlerde kullanılmak üzere farklı materyallerden farklı özelliklerde dayanaklar üretmektedir. Bu materyaller arasından seçim yapılırken materyallerin özelliklerine göre vakaya en uygun olanları tercih edilmiştir. Vaka 1'de kullanılan geçici dayanak (temporary snap abutment) implanta doğrudan yerleştirilerek vida gereksinimini ortadan kaldırmaktadır. Bu durum geçici restorasyonun provası sırasında kolaylık sağlarken vida sıkılıp gevşetilmediği için implanta rotasyonel kuvvet iletiminin önüne geçmektedir. Vaka 2'de kullanılan PEEK geçici dayanak, biyouyumluluğu ve düşük plak tutulumu göstermesi, diş rengine yakın rengi ile estetik bölgede kullanıma uygun olması, hastaya uygun olarak frez ile kolayca şekillendirilebilmesi ve maliyetinin düşük olması gibi avantajlara sahiptir. ${ }^{20}$

İmmediat yükleme ile ilgili daha fazla uzun dönemli ve iyi tasarlanmış randomize klinik çalışmalara intiyaç duyulmaktadır. İmmediat yükleme yapılmadığı durumlarda ise implant çevresi yumuşak dokunun doğal çıkış profiline sahip olabilmesi amacıyla geçici protezler kullanılabilmektedir. Vaka 3'te geleneksel iyileşme periyodu sonrası dişeti seviyesinin düzenlenmesi ve çıkış profilinin oluşturulması amacıyla geçici restorasyon kullanılmıştır. Daha sonra bu çıkış profilinin silikon ölçü materyali kullanılarak kopyalanması ile hazırlanan dişeti formuna uygun daimi restorasyonun hazırlanması sağlanmıştır. Özellikle anterior bölgede doğal yumuşak doku konturunun oluşturulması estetik olarak iyi sonuçlar verse de hastanın nihai proteze ulaşma süresi uzamaktadır. Ancak hem estetik hem de fonksiyonel olarak uzun dönemli kalıcı restorasyonlar üretilmesi sağlanmaktadır.

\section{SONUÇ}

$\mathrm{Bu}$ vakaların sunumunda estetik bölgelerde farklı yükleme protokolleri ile implant destekli kron restorasyonları uygulanan hastalarda yumuşak doku konturunun oluşturulmasının aşamaları aktarılmıştır. İmmediat restorasyonlarla hastalara kısa sürede estetik görünüm kazandırılırken geleneksel iyileşme periyodu sonrası yumuşak doku konturunun oluşturulması ile de implant çevresindeki dokuya kaybedilen hacim kazandırılmıştır. Tüm hastalar restorasyonları estetik olarak başarılı bulmuş, takip sürecinde restorasyonlarda ve çevre yumuşak dokuda herhangi bir olumsuzlukla karşılaşılmamıştır.

Uygun vakalarda immediat restorasyonların yapımı ve estetik olarak kritik bölgelerde hem yumuşak dokunun şekillendirilmesini hem de hastanın kısa sürede diş eksikliğinin giderilmesini sağlamaktadır. Geleneksel iyileşme protokolü tercih edilen vakalarda ise ikinci aşama cerrahi sonrasında geçici restorasyonlarla yumuşak doku şekillendirmesi ile doğal görünüm sağlanabilmektedir.

\section{KAYNAKLAR}

1. Stanley, M, Braga, FC, Jordao, BM. Immediate loading of single implants in the anterior maxilla: A 1-year prospective clinical study on 34 patients. Int J Dent 2017;2017:8346496.

2. Morton, D, Pollini, A. Evolution of loading protocols in implant dentistry for partially dentate arches. Periodontol 2000 2017;73:152-77.

3. Bhekare, A, Elghannam, M, Somji, S, Florio, S, Suzuki, T. Case Selection Criteria for Predictable Immediate Implant Placement and Immediate Provisionalization. J Oral Biol 2018;5:6.

4. González-Martín, O, Lee, E, Weisgold, A, Veltri, M, Su, 
H. Contour management of implant restorations for optimal emergence profiles: guidelines for immediate and delayed provisional restorations. Int $\mathrm{J}$ Periodontics Restorative Dent 2020;40:61-70.

5. Kan, JYK, Rungcharassaeng, K, Deflorian, M, Weinstein, T, Wang, HL, Testori, T. Immediate implant placement and provisionalization of maxillary anterior single implants. Periodontol 2000 2018;77:197-212.

6. Peñarrocha-Oltra, D, Soto-Peñaloza, D, Peñarrocha-Diago, M. Immediate loading in implantology. Clin Dent Rev 2020;4:1-11.

7. Kolinski, M, Hess, P, Leziy, S, Friberg, B, Bellucci, G, Trisciuoglio, D, et al. Immediate provisionalization in the esthetic zone: 1-year interim results from a prospective single-cohort multicenter study evaluating 3.0-mm-diameter tapered implants. Clin Oral Investig 2018;22:2299-308.

8. Holst, S, Blatz, MB, Hegenbarth, E, Wichmann, M, Eitner, S. Prosthodontic considerations for predictable single-implant esthetics in the anterior maxilla. J Oral Maxillofac Surg 2005;63:89-96

9. Huynh-Ba, G, Oates, TW, Williams, MAH. Immediate loading vs. early/conventional loading of immediately placed implants in partially edentulous patients from the patients' perspective: A systematic review. Clin Oral Implants Res 2018;29:255-69.

10. Buser, D, Sennerby, L, De Bruyn, H. Modern implant dentistry based on osseointegration: 50 years of progress, current trends and open questions. Periodontol 2000 2017;73:7-21.

11. Mangano, C, Raes, F, Lenzi, C, Eccellente, T, Ortolani, M, Luongo, G, et al. Immediate loading of single implants: a 2-year prospective multicenter study. Int J Periodontics Restorative Dent. 2017;37:69-78.

12. Tettamanti, L, Andrisani, C, Bassi, MA, Vinci, R, SilvestreRangil, J, Tagliabue, A. Immediate loading implants: review of the critical aspects. Oral Implantol 2017;10:129-39.
13. den Hartog, L, Raghoebar, GM, Stellingsma, K, Vissink, A, Meijer, HJ. Immediate Loading of Anterior Single-Tooth Implants Placed in Healed Sites: Five-Year Results of a Randomized Clinical Trial. Int J Prosthodont 2016;29:584-91.

14. Chen, J, Cai, M, Yang, J, Aldhohrah, T, Wang, Y. Immediate versus early or conventional loading dental implants with fixed prostheses: A systematic review and meta-analysis of randomized controlled clinical trials. J Prosthet Dent 2019;122:516-36.

15. Donos, N, Horvath, A, Calciolari, E, Mardas, N. Immediate provisionalization of bone level implants with a hydrophilic surface. A five-year follow-up of a randomized controlled clinical trial. Clin Oral Implants Res 2019;30:139-49.

16. De Rouck, T, Collys, K, Cosyn, J. Single-tooth replacement in the anterior maxilla by means of immediate implantation and provisionalization: a review. Int J Oral Maxillofac Implants 2008;23:897-904.

17. De Rouck, T, Collys, K, Wyn, I, Cosyn, J. Instant provisionalization of immediate single-tooth implants is essential to optimize esthetic treatment outcome. Clin Oral Implants Res 2009;20:566-70.

18. den Hartog, L, Raghoebar, GM, Stellingsma, K, Vissink, A, Meijer, HJ. Immediate non-occlusal loading of single implants in the aesthetic zone: a randomized clinical trial. J Clin Periodontol 2011;38:186-94.

19. Hall, JA, Payne, AG, Purton, DG, Torr, B, Duncan, WJ, De Silva, RK. Immediately restored, single-tapered implants in the anterior maxilla: prosthodontic and aesthetic outcomes after 1 year. Clin Implant Dent Relat Res 2007;9:34-45.

20. Akay, C, Ersöz, MB. PEEK in dentistry, properties and application areas. Int Dent Res 2020;10:60-5. 